\title{
DASAR HUKUM HAK PATEN
}

\author{
Yeni susanti \\ 165100114 \\ Fakultas Komputer, 448757272 \\ yenisusanti.student@umitra.ac.id
}

\begin{abstract}
Dasar hukum hak paten sendiri sudah sangat lengkap dijelaskan dalam peraturan Undang Undang hak paten nomor 14 tahun 2001. Dalam Undang-Undang yang disusun pemerintah tersebut tertulis bahwa pengajuan hak paten atas suatu invensi atau penemuan memiliki syarat yang perlu dipenuhi.

Di Indonesia sendiri hak paten akan sangat dilindungi guna melindungi hak kekayaan intelektual setiap rakyat Indonesia. Menurut peraturan undang-undang yang berlaku yakni Nomor 14 Tahun 2001 inventor yang memiliki hak paten akan suatu produk atau gagasan, memiliki kuasa penuh dan dapat memproses oknum yang melakukan plagiat, menyebarkan dan memperjualbelikan produk yang dipatenkan tersebut ke jalur hukum sesuai dengan dasar hukum hak paten mengenai pelanggaran ketentuan pidana Bab XV.
\end{abstract}

Kata Kunci : Dasar hukum hak paten

\section{A. INTRODUCTION Materi $\mathrm{Ke} 1$ dasar hukum hak paten}

Dasar hukum hak paten sendiri sudah sangat lengkap dijelaskan dalam peraturan Undang Undang hak paten nomor 14 tahun 2001. Dalam UndangUndang yang disusun pemerintah tersebut tertulis bahwa pengajuan hak paten atas suatu invensi atau penemuan memiliki syarat yang perlu dipenuhi. Suatu invensi tidak dapat dengan mudah diajukan hak patennya, jika invensi tersebut tidak benar-benar murni hasil dari penemuan terbaru yang dimiliki inventor. Penemuan tersebut juga tidak bisa dipatenkan jika tidak memiliki nilai ekonomis yang tinggi, tidak dapat diproduksi secara masal, dan penemuan tersebut tidak bersifat umum atau mudah ditemukan. 
Salah satu contoh hak paten dapat dilihat pada perusahaan besar yang terkemuka di Amerika yakni Apple. Apple merupakan salah satu produsen teknologi yang terus berinovasi dengan membangun teknologi baru dan mematenkan teknologi tersebut dalam merek dagangnya. Salah satu teknologi yang dipatenkan adalah dengan adanya pengoperasian satu tombol pada setiap produk apple yang menggunakan sistem touchscreen. Tentunya teknologi yang menjadi ciri khasnya ini tidak dapat digunakan oleh perusahaan lain yang bergerak dibidang yang sama.

Ketentuan Pidana Bagi Pelanggar Hak Paten

Di Indonesia sendiri hak paten akan sangat dilindungi guna melindungi hak kekayaan intelektual setiap rakyat Indonesia. Menurut peraturan undangundang yang berlaku yakni Nomor 14 Tahun 2001 inventor yang memiliki hak paten akan suatu produk atau gagasan, memiliki kuasa penuh dan dapat memproses oknum yang melakukan plagiat, menyebarkan dan memperjualbelikan produk yang dipatenkan tersebut ke jalur hukum sesuai dengan dasar hukum hak paten mengenai pelanggaran ketentuan pidana Bab XV.

Hal tersebut ditulis jelas dalam UU Nomor 14 Tahun 2001 Pasal 130 mengenai ketentuan pidana, yakni orang yang dengan sengaja dan tanpa pemberian hak yang jelas melakukan pelanggaran seperti yang telah dijabarkan pada Pasal 16 yakni mengenai penjuabelian, pengimporan dan pembuatan produk dalam skala besar untuk didistribusikan pada produk yang telah memiliki hak paten, akan diberlakukan tindak pidana penjara paling lama 4 tahun dan/atau didenda maksimal sebanyak $\mathrm{Rp}$ 500.000.000,00.

Selain itu ada pula peraturan yang menegaskan pelanggaran pidana pada hak paten sederhana yang tertuang dalam pasal 131 .

Pasal tersebut menyebutkan bahwa pihak yang dengan sengaja dan tanpa pemberian hak yang jelas melakukan pelanggaran hak paten sederhana seperti yang telah dijabarkan pada Pasal 16 yakni mengenai penjuabelian, pengimporan dan pembuatan produk dalam skala besar untuk didistribusikan pada produk yang telah memiliki hak paten, akan diberlalukan tindak pidana penjara paling lama 2 tahun dan/atau didenda maksimal sebanyak Rp 250.000.000,00.

Dasar Hukum Kewajiban Bagi

Pemegang Hak Paten

- Selain hak yang akan diterima oleh pemilik paten, ada pula dasar hukum hak paten yang 


\section{mengatur kewajiban pemilik paten dalam pemakaian atau penggunaan produknya yang telah dipatenkan, antara lain:}

\author{
1. Pada Pasal 17 ayat 1 sampai 4, \\ bahwa pemilik paten wajib \\ memberlakukan produksi produk atau \\ proses yang telah dipatenkan di \\ Indonesia.
}

2. Pada Pasal 18, tertulis bahwa pemilik hak paten dan lisensi perlu membayar biaya tahunan guna memperpanjang masa berlakunya hak paten sesuai dengan yang telah disepakati.

Demikian beberapa peraturan mengenai hak dan kewajiban yang perlu diketahui oleh pemilik hak paten, untuk menjaga keberlangsungan hak paten atas produknya dan juga melindungi produk yang dipatenkan dari oknum yang tidak bertanggung jawab seperti yang tertera jelas pada UU Hal Paten Nomor 14 Tahun 2001.

\section{B. CONCLUSION}

Kesimpulan dari materi ini adalah

Dasar hukum hak paten sendiri sudah sangat lengkap dijelaskan dalam peraturan Undang Undang hak paten nomor 14 tahun 2001. Dalam
Undang-Undang yang disusun pemerintah tersebut tertulis bahwa pengajuan hak paten atas suatu invensi atau penemuan memiliki syarat yang perlu dipenuhi. Dan memiliki contoh hak paten dapat dilihat pada perusahaan besar yang terkemuka di Amerika yakni Apple. Apple merupakan salah satu produsen teknologi yang terus berinovasi dengan membangun teknologi baru dan mematenkan teknologi tersebut dalam merek dagangnya.

penggunaan produknya yang telah dipatenkan, antara lain:

1. Pada Pasal 17 ayat 1 sampai 4, bahwa pemilik paten wajib memberlakukan produksi produk atau proses yang telah dipatenkan di Indonesia. 2. Pada Pasal 18, tertulis bahwa pemilik hak paten dan lisensi perlu membayar biaya tahunan guna memperpanjang masa berlakunya hak paten sesuai dengan yang telah disepakati.

\section{ACKNOWLEDGEMENT}

University Of Indonesia University Of Mitra Indonesia

Telkom University University Of Mellbourne Saitama University 
[1] A. S. Putra And O. M. Febriani, "Knowledge Management Online Application In Pdam Lampung Province," In Prosiding International Conference On Information Technology And Business (Icitb), 2018, Pp. 181-187.

[2] A. S. Putra, O. M. Febriani, And B. Bachry, "Implementasi Genetic Fuzzy System Untuk Mengidentifikasi Hasil Curian Kendaraan Bermotor Di Polda Lampung," J. Sist. Inf. Dan Manaj. Basis Data, Vol. 1, No. 1, Pp. 21-30, 2018.

[3] O. M. Febriani And A. S. Putra, "Sistem Informasi Monitoring Inventori Barang Pada Balai Riset Standardisasi Industri 
Bandar Lampung," J. Inform., Vol. 13, No. 1, Pp. 90-98, 2014.

[4] Putra, Arie Setya. "2018 Artikel Struktur Data, Audit Dan Jaringan Komputer." (2018).

[5] Putra, A. S. (2018, July 17). Paperplain Fundamental Create Application With Borland Delphi 7.0 University Of Mitra Indonesia. Retrieved From Osf.Io/Pbrn9.

\section{E. REFERENCE (Based APA)}

Putra, A. S., Aryanti, D. R., \& Hartati, I. (2018, November). Metode SAW (Simple Additive Weighting) sebagai Sistem Pendukung Keputusan Guru Berprestasi (Studi Kasus: SMK Global Surya). In Prosiding Seminar Nasional Darmajaya (Vol. 1, No. 1, pp. 85-97).

Sari, D. P., Febriani, O. M., \& Putra, A. S. (2018, November). Perancangan Sistem Informasi SDM Berprestasi pada SD Global Surya. In Prosiding Seminar Nasional Darmajaya (Vol. 1, No. 1, pp. 289-294).

Putra, A. S. (2018). Paperplain: Execution Fundamental Create Application With Borland Delphi 7.0 University Of Mitra Indonesia.

Putra, A. S., Sukri, H., \& Zuhri, K. Sistem Monitoring Realtime Jaringan
Irigasi Desa (JIDES) Dengan Konsep Jaringan Sensor Nirkabel. IJEIS (Indonesian Journal of Electronics and Instrumentation Systems), 8(2), 221232.

Darmawan, A., Yuliawati, D., Marcella, O., \& Firmandala, R. (2016). Sistem Absensi dan Pelaporan Berbasis Fingerprint dan SMS Gateway. EXPLORE, 7(1).

Febriani, O. M., Wahyuni, T., \& Yusuf, S. (2017). DESIGN OF WEBSITE-BASED INFORMATION SYSTEM FOR EDOCUMENT ADMINISTRASI IN THE COMMUNITY SERVICE UNIT (A Case Study at Rajabasa District). INTERNATIONAL JOURNAL OF COMPUTERS \& TECHNOLOGY, 16(7), 7010-7020.

Febriani, O. M., \& Wahyuni, T. (2017, October). PERANCANGAN SISTEM E-DOCUMENT ADMINISTRASI LOGBOOK PENELITIAN PADA UNIT LAYANAN DI BANDAR LAMPUNG. In Prosiding Seminar Nasional Darmajaya (Vol. 1, No. 1, pp. 187-194).

Febriani, O. M., \& Permadi, A. B. (2017). Implementasi Sistem Aplikasi Data Bimbingan dan Pelanggaran Siswa pada Sekolah Menengah Atas di Lampung Tengah dengan Metode Analisis dan Desain Sistem Terdistribusi (SSAD). EXPERT, 7(1).

Febriani, O. M., \& Ambarwati, L. (2015). PERANCANGAN APLIKASI PENGOLAHAN DATA PENJUALAN UKM KELANTING 
KHAS TELO DESA SIDOHARJO KECAMATAN JATI AGUNG KABUPATEN LAMPUNG SELATAN. Jurnal Teknologi Informasi dan Bisnis Pengabdian Masyarakat Darmajaya, 1(1), 77-95.

Febriani, O. M. (2015). Rancang Bangun Aplikasi Ecommercemenggunakan Freewebstore pada UKM Kelanting di Desa Sidoharjo Lampung Selatan. Prosiding Sembistek 2014, 1(02), 446-458. 